\title{
Cytotaxonomic Studies on the Two Cultivated Species and the Wild Relatives in the Genus Echinochloa
}

\author{
Tomosaburo Yabuno \\ College of Agriculture, University of Osaka Prefecture, \\ Sakai, Osaka Prefecture, Japan
}

Received May 9, 1962

\section{Introduction}

The genus Echinochloa comprises about twenty species of annual or perennial grasses, and many of them are common to paddy fields.

The cultivated species, E. frumentacea (Roxb.) Link, is known as one of millets; and Sawa millet, Sanwa millet, poor man's millet, billion dollar grass, Japanese barnyard millet, barnyard millet and Japanese millet, etc. have been applied as the popular name to this cultivated species. This millet is grown for its grain as well as its forage in many parts of the Far East, being cultivated often in places where rice does not grow well. This crop is called Sawa or Sanwa (Mansfeld 1952), and locally known as Sama in India (Richharia 1957). Not much genetic work has been done on this crop.

In an earlier paper the author (Yabuno 1953) described that the basic number of Echinochloa is 9, and Japanese wild species, E. crus-galli (Linn.) Beauv., contains tetra- and hexaploid varieties, and Japanese cultivated strains are hexaploid. At the same time it was concluded that Japanese cultivated strains and Japanese hexaploid varieties of $E$. crus-galli have the same genome constitution in common, and it was further assumed that hexaploid varieties of $E$. crus-galli is an ancestral form of the cultivated species. Afterwards seeds of Malayan and Javanese strains of E. colona (L.) Link and Indian and Chinese cultivated strains could be obtained. Cross experiments were tried using these strains and hexaploid varieties of E. crus-galli. Their hybrids were easily obtained. In this paper the phylogenetic relationships of the cultivated species to the wild species of Echinochloa will be considered on the basis of the results of cytological investigations on their hybrids.

\section{Materials and methods}

In this study four strains of E. crus-galli, two strains of E. colona and five cultivated strains were used. The sources of these materials are shown in Table 1.

Of these materials W3 is the strain which was used in the controlled crosses with Japanese cultivated strains in a previous study (Yabuno 1953).

For cytological studies, spikelets were fixed in acetic alcohol $(1: 3)$ and 
the chromosomes in PMC's were observed by the acetocarmine stain technique. The technique of hybridization is the same as that previously employed (Yabuno 1953).

Table 1. Source of materials

\begin{tabular}{l|l|c}
\hline \multicolumn{1}{c|}{ Species } & Strain & Source \\
\hline Echinochloa crus-galli (L.) Beauv. & 563 & Nepal \\
$\begin{array}{l}\text { E. crus-galli var. praticola Ohwi } \\
\text { E. crus-galli var. caudata (Roshev.) }\end{array}$ & W3 & Japan \\
Kitagawa & In-9 & Coimbatore, India \\
E. colona (L.) Link & M-A.-C & California, U.S.A. \\
& J-5 & Malaya \\
The cultivated species & & Java \\
Indian strain & In-1 & Coimbatore, India \\
& In-3 & do. \\
& In-6 & do. \\
Chinese strain & In-11 & do. \\
& 5844 & Hulan, China \\
\hline
\end{tabular}

In order to examine pollen fertility, anthers were collected at interval of a few days from florets just flowering, and pollen grains were stained by iodine-potassium iodide.

\section{Observations}

A. Morphology of the wild and the cultivated species

Two wild species, E. crus-galli and E. colona, can be distinguished in some characteristics. Principal characters distinguishing them are given in Table 2.

Table 2. Principal characters distinguishing the two wild species of Echinochloa

\begin{tabular}{|c|c|c|}
\hline \multirow{2}{*}{ Characters } & \multicolumn{2}{|c|}{ Species } \\
\hline & E. crus-galli Beauv. & E. colona Link \\
\hline Panicle & Usually nodding & Erect \\
\hline Rachilla & $\begin{array}{l}\text { Rather close on a rachis, more or } \\
\text { less branched }\end{array}$ & Rather distant on a rachis, simple \\
\hline Spikelet & Often not arranged in rows & Usually arranged in 4 rows \\
\hline Awn & Variable in length & Awnless \\
\hline Stigma color & White or red & Blackish-purple \\
\hline Anther color & Brown or yellow & Purple \\
\hline
\end{tabular}

Panicles of some strains of these two wild species and the cultivated species are shown in Figs. $1 \mathrm{a}$ and $1 \mathrm{~b}$.

The essential difference between the cultivated and the wild species can be recognized in the deciduous character of spikelets, i.e. the cultivated species has non-deciduous character and both E. colona and E. crus-galli possess deciduous character of spikelets. 
Leaf, stem and panicle of the cultivated species are more gigantic than that of the wild species. With respect to panicle characters Indian and ChinoJapanese cultivated strains tend to resemble E. colona and E. crus-galli respectively.

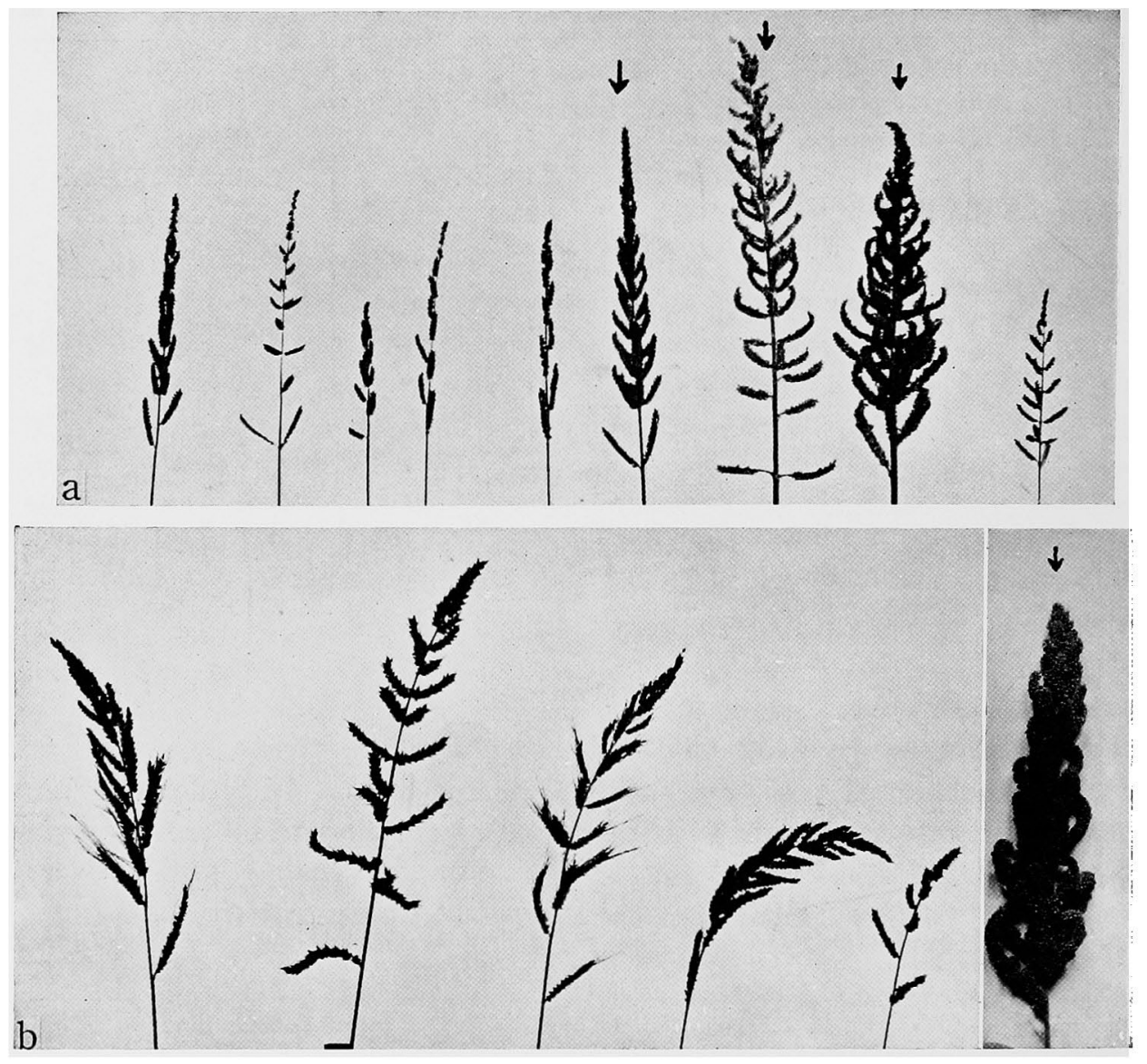

Fig. 1. Panicles of the two wild species and the cultivated species of Echinochloa. a, E. colona and Indian cultivated strains. b, E. crus-galli and Japanese cultivated strain. Panicles of the cultivated strains are indicated by arrows.

B. Cytology of the wild species, the cultivated species and the $F_{1}$ hybrids.

Meiosis was observed in all strains of E. colona and E. crus-galli and in five cultivated strains. It was normal in all of them, and 27 bivalents were observed at metaphase I. E. colona, Indian and Chinese cultivated strains and varieties of $E$. crus-galli used in this study can be therefore said to be hexaploid because the basic number of Echinochloa is 9. All these strains showed the high pollen- and seed fertility.

Four strains of E. crus-galli used in this study hybridize easily between them, and it was confirmed that they have the same genome constitution. All five $F_{1}$ hybrids between two strains of $E$. colona and four Indian cultivated 
strains were quite normal in the meiotic division of PMC's, and 27 bivalents were observed at metaphase I (Fig. 2d). Many characters of the $F_{1}$ hybrids are intermediate between those of the parent plants except for the deciduous character of spikelets (Fig. 2ac).

It can be therefore concluded that Indian cultivated strains consist of genomes which are completely homologous with that of $E$. colona.

In spite of the normal meiotic division all the $F_{1}$ hybrids showed a marked high sterility in various degree (Table 3). Significant difference in pollen fertility was not found between anthers which were collected at intervals of a few days. Normal pollen percentage seems to depend upon the combination of parental strains.

The growth fo four $F_{1}$ plants

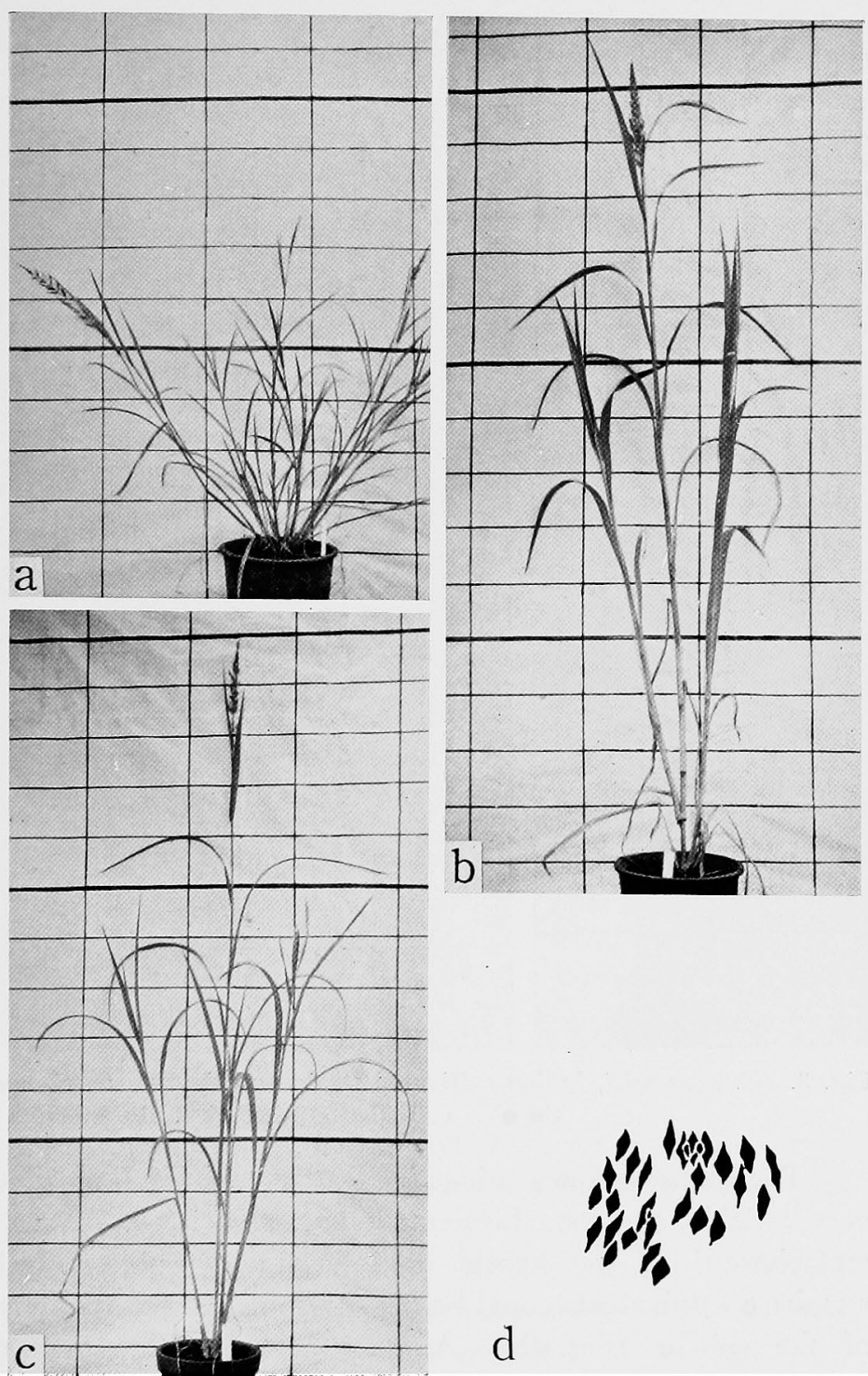

Fig. 2. E. colona, Indian cultivated strain and the $\mathrm{F}_{1}$ hybrid. a, $E$. colona (J-5). b, Indian cultivated strain (In-3). c, the $F_{1}$. d, metaphase I of the $F_{1}$ showing 27 bivalents.

between Indian cultivated strains and E.crus-galli and that of an $F_{1}$ plant of Indian strain $\times$ Chinese strain of the cultivated species were as vigorous as their parents (Fig. 3). 
Meiotic irregularities, i.e. quadri- trivalents, univalents, laggards, and micronuclei, were observed in all of these hybrids. The general features of meiotic division of these five hybrids were as follows :

Table 3. Pollen fertility of the $\mathrm{F}_{1} \mathrm{~s}$ between $E$. colona and Indian cultivated strains

\begin{tabular}{c|c|c|c}
\hline \hline Hybrid & $\begin{array}{c}\text { No. of pollen grains } \\
\text { examined }\end{array}$ & $\begin{array}{c}\text { No. of good pollen } \\
\text { grains }\end{array}$ & $\begin{array}{c}\text { Normal pollen } \\
\text { percentage }\end{array}$ \\
\hline J-5 $\times$ In-1 & 6050 & 1918 & 31.70 \\
J-5 $\times$ In-3 & 29354 & 5555 & 18.92 \\
M- $1 \times$ In-6 & 9390 & 3628 & 38.63 \\
M-1 $\times$ In-3 & 6771 & 2022 & 29.86 \\
\hline
\end{tabular}
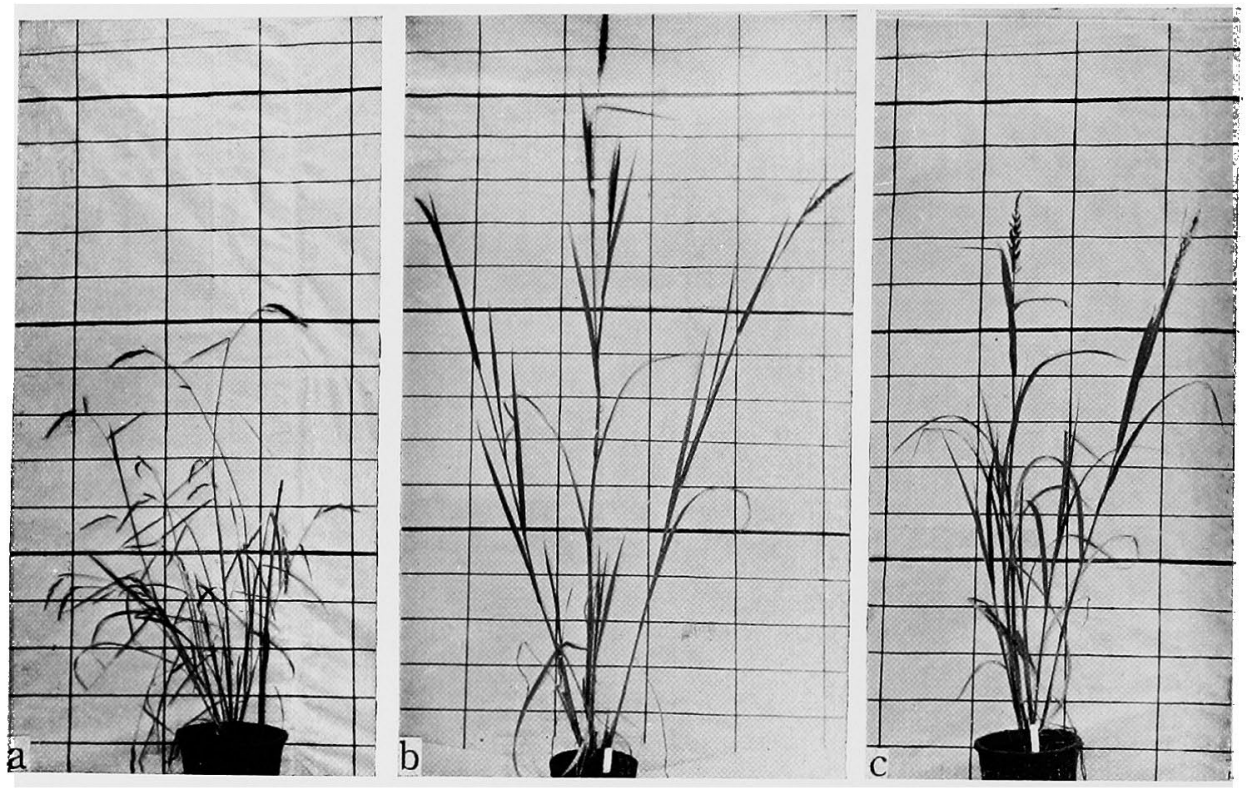

Fig. 3. E. crus-galli, Indian cultivated strain and the $F_{1}$, a, E. crus-galli (U.S.A.-C). b, the $F_{1}$. c, Indian cultivated strain (In-6).

The chromosome conjugations at metaphase I of all these hybrids were very variable, and some bivalents loosely associated. Fig. 4a shows a meiotic metaphase I of the hybrid of Indian and Chinese cultivated strains. At anaphase I univalents could be observed in process of division at the equator of the spindle (Fig. 4b). At a somewhat later stage the half-univalents proceeded to the opposite poles. A few fragments remained in the cytoplasm were seen at telophase I. The single chromatids that derived from the division of univalents at anaphase I, were distributed to the poles at random at anaphase II. Laggardism was also observed at this stage.

A summary of the chromosome configurations of these five hybrids is given in Table 4.

The data for these five hybrids were combined in the column of total 
of Table 4 since all hybrids behaved much the same in meiosis.

The average chromosome configurations of hybrids In $-6 \times$ U.S.A. - C,

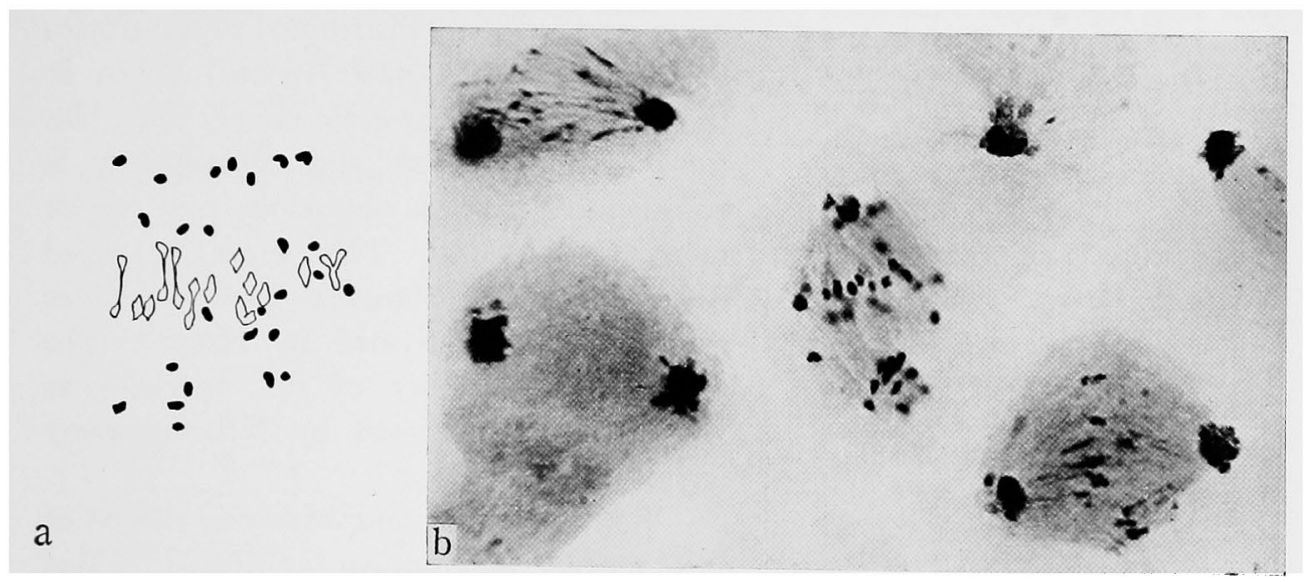

Fig. 4. Meiotic division of the $F_{1}$ hybrid between Indian cultivated strain and Chinese cultivated strain. a, chromosome pairing at metaphase I, 2 III $+11_{I I}+26$ I. b, anaphase I showing division of univalents at the equator.

In- $9 \times$ In- 1, W $3 \times$ In- $1,563 \times$ In- 1 , and In- $11 \times 5844$ are

$$
\begin{aligned}
& 0.15_{\text {IV }}+1.14_{\text {III }}+11.29_{\text {II }}+27.40_{\text {II }}, \\
& 0.11_{\text {IV }}+0.86_{\text {III }}+11.60_{\text {II }}+27.78_{\text {I }}, \\
& 0.31_{\text {IV }}+1.38_{\text {III }}+11.63_{\text {II }}+25.36_{\text {I }}, \\
& 0.08_{\text {IV }}+1.08_{\text {III }}+13.36_{\text {II }}+23.72_{\text {I }}, \\
& \text { and } \quad 0.70_{\text {III }}+11.27_{\text {II }}+29.36_{\text {I }}, \quad \text { per cell respectively, }
\end{aligned}
$$

and the average chromosome configuration which can be obtained by combining the data for all these five hybrids is

$$
0.13_{\mathrm{IV}}+1.03_{\mathrm{III}}+11.81_{\mathrm{II}}+26.77_{\mathrm{I}} \text {. }
$$

The chromosome pairing observed in the hybrids may be auto- or allosyndetic. At the present there is no evidence for judging whether autoor allosyndesis are taking place.

In the consequence of the irregular meiotic division of the $F_{1}$ hybrids described above, micronuclei were formed in the microspores of the quartets. The frequency of the microspores with various numbers of micronuclei is shown in Table 5 .

The distribution of micronucleus numbers was ranged from one to five, and the deviation in percentage of microspores with micronuclei was considerably marked between the hybrids.

Pollen grains were empty in all the $\mathrm{F}_{1}$ hybrids between Indian cultivated strains and E. crus-galli or Chinese cultivated strain, and anthers did not dehisce at flowering time. The hybrid plants set no seed in free pollination. 


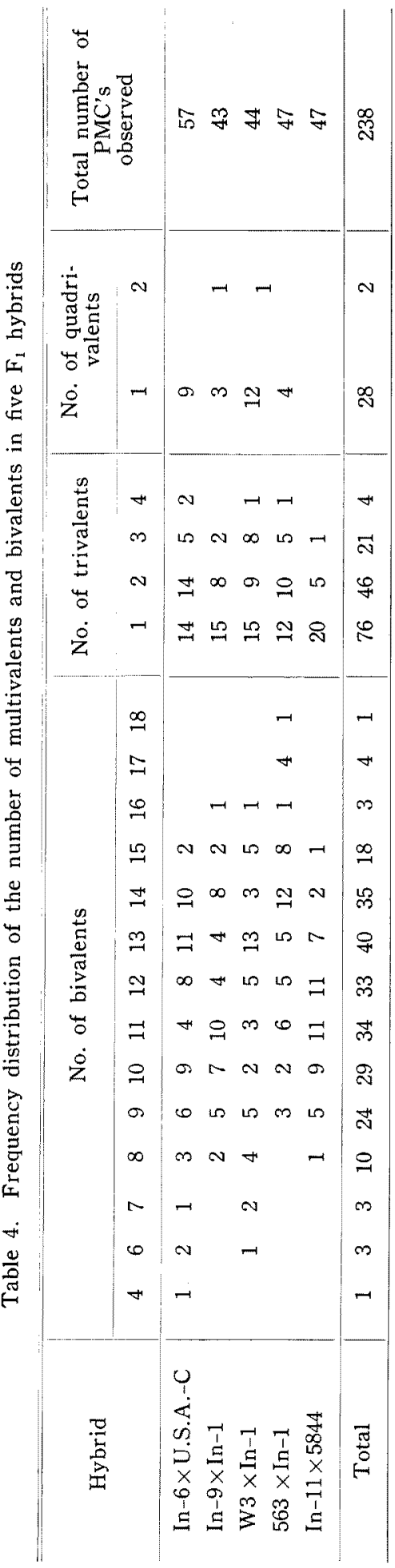

\section{Discussion}

E. colona (L.) Link is an annual tufted grass, and is widely distributed in the tropics of Asia, America and Africa. When in the young state this grass closely resembles the young rice plant, and consequently is considered to be an obnoxious pest in rice fields (Bor 1960). This grass is called Shama in India (Mansfeld 1952), and was at one times cultivated in Egypt. The chromosome number of this species was reported to be $2 \mathrm{n}=48$ by Krishnaswamy and Raman (1949).

Both Javanese and Malayan strains of this species and Indian cultivated strains used in the present investigation possess $\mathrm{n}=27$ chromosomes. The cultivated species, E. frumentacea (Roxb.) Link has been classified as a variety of $E$. colona, $E$. colona var. frumentacea Ridley, by some taxonomists. Krishnaswamy described in his paper (Krishnaswamy 1951) that $E$. colona hybridizes with the cultivated millet, $E$. colona var. frumentacea, giving rise to a large number of intermediates.

The hybrids of $E$. colona and Indian cultivated strains could be easily obtained in the present experiment. All these hybrids formed 27 bivalents at metaphase I, and the meiotic divisions proceed normally, although a marked high pollen sterility appeared in all of them. It can be thus concluded E. colona and Indian cultivated strains have the same genome constitution.

This relationship can be compared with that of hexaploid varieties of $E$. crus-galli (L.) Beauv. and Japanese cultivated strains, which was elucidated by a previous study (Yabuno 1953).

E. crus-galli is a polymorphic species in ecological and morphological characters, and can be found all round the world, rather more plentifully in warm temperate 
regions than in the tropics. Four $F_{1}$ hybrids between Indian cultivated strains and hexaploid varieties of E. crus-galli and an $\mathrm{F}_{1}$ hybrid of Indian- and Chinese cultivated strains were found to show meiotic irregularity, and they

Table 5. Frequency of microspores with micronuclei

\begin{tabular}{|c|c|c|c|c|}
\hline \multirow{2}{*}{$\begin{array}{c}\text { No. of } \\
\text { micronuclei/microspore }\end{array}$} & \multicolumn{4}{|c|}{ Frequency of microspores } \\
\hline & In $-9 \times \operatorname{In}-1$ & W3 $\times$ In-1 & $563 \times \operatorname{In}-1$ & In-11 $\times 5844$ \\
\hline 0 & $16(8.6 \%)$ & $86(39.4 \%)$ & $1197(64.3 \%)$ & $68(23.9 \%)$ \\
\hline 1 & $98(52.7)$ & $102(46.8)$ & $581(31.2)$ & $110(38.7)$ \\
\hline 2 & $51(27.4)$ & $22(10.1)$ & $82(4.4)$ & $77(27.1)$ \\
\hline 3 & $16(8.6)$ & $7(3.2)$ & $2(0.1)$ & $23(8.1)$ \\
\hline 4 & $3(1.6)$ & $1(0.5)$ & $0(0.0)$ & $5(1.8)$ \\
\hline 5 & $2(1.1)$ & $0(0.0)$ & $0(0.0)$ & $1(0.4)$ \\
\hline $\begin{array}{l}\text { Total number of micro. } \\
\text { spores observed }\end{array}$ & 186 & 218 & 1862 & 284 \\
\hline $\begin{array}{l}\text { Percentage of micro- } \\
\text { spores with micronuclei }\end{array}$ & $91.3 \%$ & $60.5 \%$ & $35.7 \%$ & $76.0 \%$ \\
\hline
\end{tabular}

showed a wide distribution in the range of chromosome pairing. But all these hybrids hehaved much the same in meiosis. From the data on chromosome associations for these five hybrids the average chromosome configuration,

$$
0.13_{\mathrm{IV}}+1.03_{\mathrm{III}}+11.81_{\mathrm{II}}+26.77_{\mathrm{I}} \text {, }
$$

could be summarized.

Although in this study the genomic formula can not be given to the two wild species, i.e. E. colona and E. crus-galli, and Indian and Chino-Japanese cultivated strains, it can be now safely said that E. colona and hexaploid varieties of $E$. crus-galli do not have the same genome constitution, and the same conclusion can be adopted to Indian and Chino-Japanese cultivated strains.

E. frumentacea (Roxb.) Link is the specific name originally given to the cultivated species of India (Roxburgh 1820), but it has been applied further to Chino-Japanese cultivated strains by many taxonomists and agronomists. It is therefore reasonable to separate Chino-Japanese cultivated species from $E$. frumentacea considering the cytological evidence mentioned above, and the new specific name, E. utilis Ohwi et Yabuno was given to ChinoJapanese cultivated strains. Accordingly, all four Indian cultivated strains and Chinese cultivated strain, which were used in this study, belong to $E$. frumentacea and $E$. utilis respectively, and the four Japanese cultivated strains which were used in the previous cross experiments reported in 1952 by the author are not $E$. frumentacea but $E$. utilis.

Ohwi described that " $E$. frumentacea of Japan has been said to be derived from $E$. crus-galli or $E$. colona but it is morphologically tends to 
resemble the former rather than the latter species" (Ohwi 1942).

On the basis of morphology and cytology the present author assumes that $E$. frumentacea, which is the cultivated species of India, has been derived from E. colona, on the other hand, E. utilis, which is Chino-Japanese cultivated species, has been derived from hexaploid variety of $E$. crus-galli.

One of the popular names of the cultivated species of Echinochloa, Japanese millet must have originally been given to Japanese cultivated strains, therefore, this popular name is justifiable one to $E$. utilis. On the other hand E. frumentacea is called 'Sawa' in India (Mansfeld 1952) and Sawa millet seems to be a suitable popular name for $E$. frumentacea.

\section{Summary}

Echinochloa colona (L.) Link of Malaya and Java, and Indian strains of cultivated species, E. frumentacea (Roxb.) Link, were certained to be hexaploid, $\mathrm{n}=27$, and to have the same genome constitution in common.

Although the $F_{1}$ hybrids of these two species showed a low degree of fertility, it can be assumed that E. colona is a wild form of $E$. frumentacea.

In earlier paper the author (Yabuno 1953) has confirmed that hexaploid varieties of E. crus-galli (L.) Beauv. and Japanese cultivated strains have the same genome constitution, and that the former is a wild form of the latter.

Four $\mathrm{F}_{1}$ hybrids between Indian strains of $E$. frumentacea and hexaploid varieties of $E$. crus-galli, and an $\mathrm{F}_{1}$ hybrid between Indian strain of $E$. frumentacea and Chinese cultivated strain were cytologically investigated. It is concluded that E. colona and E. crus-galli do not possess genomic constitution in common. The same conclusion can be adopted to Indian and Chino-Japanese cultivated strains. But any genomic formula was not assigned to these species in this paper.

Indian and Chino-Japanese cultivated strains have been maintained under the specific name, E. frumentacea. On the basis of the results of cytological investigations Chino-Japanese cultivated species was separated from E. frumentacea, and the new specific name, E. utilis Ohwi et Yabuno was given.

$E$. colona and E. crus-galli can be distinguished in some morphological characters, particularly with respect to panicles character, and these two wild species differ more or less in geographic distribution.

$E$. utilis and $E$. frumentacea resemble to $E$. crus-galli and $E$. colona respectively in the characteristics of panicle. From the evidences mentioned above, it is assumed that $E$. utilis has arisen from the hexaploid varieties of E. crus-galli probably in the Far East, and E. frumentacea from $E$. colona in the tropics.

\section{Literature cited}

Bor, N. L. 1960. Grasses of Burma, Ceylon, India and Pakistan. Pergamon Press. 
Krishnaswamy, N. and Raman, V. S. 1949. A note on the chromosome numbers of some economic plants of India. Curr. Sci. 18: 376-378.

- 1951. Origin and distribution of cultivated plants of South Asia: Millets. Ind. Jour. Genet. and Plant Bred. 11: 67-74.

Mansfeld, R. 1952. Zur Systematik und Nomenklatur der Hirsen. Der Züchter 22: 304-315.

Ohwi, J. 1942. Gramina Japonica III. Acta Phytotaxonomica et Geobotanica 11: 36-39.

Richharia, R. H. 1957. Plant Breeding and Genetics in India. Vol. 1. Patna, India.

Roxburgh, W. 1820. Flora Indica, ed. Carey and Wallich. Vol. 1.

Yabuno, T. 1953. Morphological and cytological studies in the genus Echinochloa. Seiken Zihô No. 6, 66-71. 